\title{
INCIDENCE OF PHLEBITIS ASSOCIATED WITH OSMOLARITY
}

\author{
Paul Joae Brett Nito ${ }^{1}$, Dewi Wulandari ${ }^{2}$ \\ \{pauljoae@unism.ac.id ${ }^{1}$.,dewiwulandari@unism.ac.id $\left.{ }^{2}\right\}$ \\ ${ }^{1}$ Pediatric Department, Nursing Program, Faculty of Health Universitas Sari Mulia, Banjarmasin, Indonesia, \\ ${ }^{2}$ Staff of nursing skills laboratory, Faculty of Health Universitas Sari Mulia, Banjarmasin, Indonesia
}

\begin{abstract}
Phlebitis is a condition where the veins (tunica intima) inflammation, characterized by pain in the affected area, swelling, erythema and palpable hard veins caused by internal and external factors. The incidence of phlebitis highest in Southeast Asia according to the CDC (2017) are in developing countries such as Malaysia (12.70\%), Philippines $(10.10 \%)$, and Indonesia $(9.80 \%)$. This study aimed to determine incidence of phlebitis associated with osmolarity in Pediatric's wards of hospitals in Banjarmasin.This cohort study used analytic observational with a sample of 80 people used consecutive sampling technique with predetermined criteria. The instruments used were observation sheet respondents and Visual Infusion phlebitis Scale (VIP Scale). Data were analyzed using chi square test. There was a significant association between osmolarity with the incidence of phlebitis $(\mathrm{p}<0.05$ ). This study recommend that nurses and medical personnel need to consider the osmolarity is given through a peripheral IV catheter
\end{abstract}

Keywords: Osmolarity, Phlebitis, Visual Infusion Phlebitis Scale

\section{Introduction}

Phlebitis is a condition where the veins (tunica intima) inflammation, characterized by pain in the affected area, swelling, erythema and palpable hard veins. [1,2,3]. factors involved in the incidence of phlebitis, among others: internal factors and external factors (factors mechanical, chemical factors, bacterial factors). [2,4].

Several factors have been associated with the incidence of phlebitis, (1) chemical factors, caused by irritation of drugs or infusion; (2) mechanical factors, location and material catheter and insertion skills; (3) The bacterial factors, migration of organisms from the skin, along the catheter to edge or from contaminated areas; and (4) patient factors / internal, infections from other locations, nutritional status, state of the veins, age, and sex. [5,6].

Phlebitis become one of the complications that often occur in intravenous therapy. [7,8]. Percentage of phlebitis in Southeast Asia every year about 10\%. Center for Disease Control and Prevention (CDC) report on 2017 the incidence of phlebitis highest in Southeast Asia such as Malaysia (12.70\%), Philippines (10.10\%), and Indonesia (9.80\%). [7]. The incidence of phlebitis was underreported in studies on 2015 Nagpal et al about from 2.3 to 67\%, Ministry of Health Indonesia reported on 2013 prevalence in public hospital $50.11 \%$ and private hospital $32.70 \%$. $[8,9,10]$.

Preliminary studies on February 2017 in a hospital at Banjarmasin based on March 2016's data reported prevalence of phlebitis rate is $6.9 \%$. According to the standards of the Infusion Nurse Society (INS), the accepted phlebitis rates is 5\%. [11]. However, research findings suggest that there is a significant discrepancy in reported incidence associated with quality of hospital services specifically morbidity and residential or outpatient duration of treatment. Longer duration of treatment impacted to individually, family, and management of hospital for hospital services quality.

\section{Method}

This cohort study used analytic observational with a sample of 80 people used consecutive sampling technique with predetermined criteria. The instruments used were observation sheet respondents and Visual Infusion phlebitis Scale (VIP Scale). Data collected between May to June 2017 throughout 24 hours by researcher or researcher assistant (Cohen's Kappa: 0.894). 


\subsection{Research Ethic}

Research ethic and research permit approved by ethical review committee of hospital and education institution. This study objective and procedure explained to parent's sample.

\subsection{Validity and Reliability}

VIP scale is a scale most used but Many phlebitis scales exist, but none has been thoroughly validated for use in clinical practice. [1]. Confirmed validity and reliability of VIP scale by Gallat P (2009) and Nekuzad (2012) correlation coefficient is 0.93. [12,13,14,15].

\section{Result}

The results of this study enabled a number of analyses that may contributed to understanding incidence of phlebitis associated with osmolarity. The number of participants 80 people were observation with VIP scale and identification Intravenous fluid therapy type.

Table. 1 Characteristics of subjects

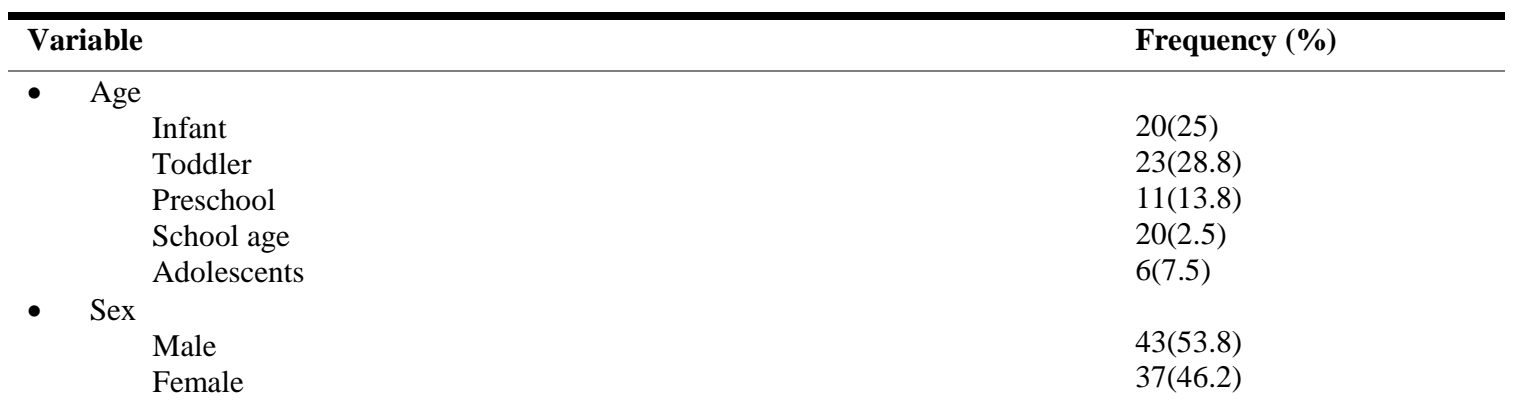

Table 1 showed the characteristics of subjects. The most age of participants was toddler 1-3 years old $(28.8 \%)$. The majority of participants was male $(53.8 \%)$.

Table. 2 Osmolarity of Intravenous fluid therapy and incidence of phlebitis

\begin{tabular}{|c|c|}
\hline Variable & Frequency $(\%)$ \\
\hline $\begin{array}{l}\text { - } \quad \text { Osmolarity infusion } \\
\text { Isotonic } \\
\text { Hypertonic } \\
\text { - } \quad \text { Incidence of phlebitis } \\
\text { No } \\
\text { Yes }\end{array}$ & $\begin{array}{l}37(46.3) \\
43(53.7) \\
68(85) \\
12(15)\end{array}$ \\
\hline
\end{tabular}

Table 2 showed Osmolarity of Intravenous fluid therapy and incidence of phlebitis. The majority of participants has hypertonic fluid solution $(53.7 \%)$. The number of incidence phlebitis is $12(15 \%)$.

Table. 3 The Relationship Osmolarity of Intravenous fluid therapy and incidence of phlebitis

\begin{tabular}{cccc}
\hline & \multicolumn{2}{c}{ Variable } & \multicolumn{2}{c}{ Frequency of incidence phlebitis } & P Value \\
\cline { 2 - 3 } & Yes & No & \\
\hline$\bullet \quad$ Osmolarity Infusion & $1(2.7)$ & $36(97.3)$ & $0,011^{\text {a }}$ \\
Isotonic & $11(25.6)$ & $32(74.4)$ & \\
Hypertonic & & & \\
\hline
\end{tabular}

a Continuity Correction Test

Based on bivariate analysis $\mathrm{p}$ value of osmolarity is $<0.011$ showed in table 3 about the relationship osmolarity of Intravenous fluid therapy and incidence of phlebitis. $p<0.011(\mathrm{p}<0.05)$ stated there was a significant association between osmolarity with the incidence of phlebitis. 


\section{Discussion}

Based on the statistical analysis stated there was a significant association between osmolarity with the incidence of phlebitis $(\mathrm{p}<0.011)$. Result of bivariate showed participants has intravenous isotonic fluid therapy that has phlebitis $1(2.7 \%)$ while participants has intravenous hypertonic fluid therapy that has phlebitis $11(25.6 \%)$. a sufficient ground of explanation the tolerance osmolarity of peripheral venous about $250-350 \mathrm{mOsm} / \mathrm{L}$, osmolarity less than $250 \mathrm{mOsm} / \mathrm{L}$ lead to cell rupture, osmolarity more than $600 \mathrm{mOsm} / \mathrm{L}$ lead to phlebitis. $[16,17,18]$.

Researcher found infant and toddler has D10\% (555 mOsm/L) and D51/2 NS (406 mOsm/L) for Intravenous fluid therapy. Both of them are hypertonic fluid solution, hypertonic fluid solution injure wall of venous and increase risk of phlebitis. Hypertonic fluid solution has higher concentration than other fluid solution, higher osmolarity than plasma serum made fluid transported out from the cell and the cells shrink.

According to results of studies Zohaib J et al (2019), Jacinto AKL et al (2014), and Gomes et al (2011) discovered there was a significant association between osmolarity with the incidence of phlebitis, fluid solution has higher osmolarity than other fluid solution increase risk of phlebitis. [22,23,24]. Salma et al reported on 2019 participants used potassium chloride (KCL) kind of hypertonic fluid solution has phlebitis. [19]. Hypertonic fluid solution considered harm venous endothelium lead to the incidence of phlebitis. [20]. Similarities with results of studies Park SM et al (2016) and Doellman D et al (2009) stated phlebitis caused by high osmolarity in that its lead to venous wall traumatic. [16,25]. In contrast to studies by Enes SMS et al (2016), Benaya A et al (2015), and Fang L et al (2011) stated there was not a significant association between osmolarity with the incidence of phlebitis. [26,27,28].

Knowledge about phlebitis is fundamental knowledge for nurse to prevent phlebitis in deliver nursing care. Nurse must know about risk factors of phlebitis, prevention action, intravenous care. Nurse and other medical personnel have responsibility to ensure the safe monitoring and management of patient's IV line stated by Pankaj Punjot et al (2018), it is act of prevention intravenous complications. [29].

\section{Conclusion}

This study recommend that nurses and medical personnel need to consider the osmolarity is given through a peripheral IV catheter. It is important because kind of osmolarity fluid therapy given through IV catheter potential lead to intravenous complications, each one of it is phlebitis.

\section{References}

[1] Ray-Barruel G, Polit DF, Murfield JE, and Rickard CM. "Infusion phlebitis assessment measures: a systematic review," Journal of Evaluation in Clinical Practice, 20(2): 191-202. (2014).

[2] Spina R, Mussa B, Tollapi L, Conti F, Cortesi E, Verna R.Adoption and application in italy of the principal guidelines and international recommendations on venous access. Minerva Med, 109:153202. DOI: 10.23736/S0026-4806.18.05552-0). (2018).

[3] Gabor M, Gillian Ray-Barruel, Vineet C, Joan W, Marianne W, Nicole M, Mattew McGrail, Claire MR.: Phlebitis Signs and Symptoms with Peripheral Intravenous Catheters. Journal of Infusion Nursing; 41(4): 260-263. (2018)

[4] Potter AP, Perry GA, Stockert AP, Hall MA. Fundamentals of nursing. Ninth Edition.USA: Elsevier. Page 675-987.(2016)

[5] Wallis MC, M. McGrail, J. Webster et al. "Risk factors for peripheral intravenous catheter failure: a multivariate analysis of data from a randomized controlled trial". Infection Control and Hospital Epidemiology, 35(1): 63-68 (2014).

[6] Clayton BD and Stock YN. Pharmacology in Nursing: An Evaluation of Adverse Practice. In: Clayton BD and Willihnganz M (Eds). Basic Pharmacology for Nurses 13th edition. Missouri: Elsevier (2010).

[7] CDC.Guidelines for the prevention of intravascular catheter-related infections. Department of Health and Human Services. Washington DC.(2017) 
[8] Nagpal P, Khera GK, Kumar Y. A study Assess the Clinical Pattern of Phlebitis among children admitted in selected hospital of Ambala, Haryana. Nursing and Midwifery Research Journal, 11(2): 68-77.(2015)

[9] Laudenbach N, Braun C, Klaverkamp L \& Hedman-Dennis S. Peripheral IV stabilization and the rate of complications in children: An exploratory study. Journal of Pediatric Nursing 29, 348-353 (2014).

[10] Rizky W. Analsis faktor yang berhubungan dengan kejadian phlebitis pada pasien yang terpasang kateter intravena di ruang bedah rumah sakit Ar. Bunda Prabumulih. Journal Ners and Midwifery Indonesia,4 (2); 102-108. (2016).

[11] Evangeline H, Supriadi D, Sunarya W. Perbedaan Kompres $\mathrm{NaCl}$ 0,9\% dengan Kompres Alkohol 70\% terhadap Penurunan Intensitas Nyeri pada Pasien Phlebitis. Jurnal Kedokteran dan Kesehatan, 2(3): 245-251.(2015).

[12] Gorski L, Hadaway L, Hagle ME, McGoldrick M, Orr M, Doellman D. Infusion Therapy Standards of Practice. Journal of Infusion Nursing. Infusion Nurses Society, 39(1S): S95-S98. ISSN 1533-1458. (2016).

[13] Bagheri-Nesami M, Shorofi SA, Hashemi-Karoie SZ, Khalilian A. The effect of sesame oil on the prevention of amiodarone-induced phlebitis. Iran J Nurs Midwifery Res, 20(3):365-370. (2015).

[14] Nekuzed N, Ashketorab TA, Mojab F, Alavi-Majd H, Azadeh P, Ehtejab G. Effect of external use of sesame oil in the prevention of chemotherapy induced phlebitis. Iran J Pharm Res, 11:10651071. (2012).

[15] Gallant P, Schultz A. Evaluation of a visual infusion phlebitis scale for determining appropriate discontinuation of peripheral intravenous catheters. J Infus Nurs, 29(6):338-34. (2006).

[16] Park SM, Jeong IS, Jun SS. Identification of Risk Factors for Intravenous Infiltration among Hospitalized Children: A Retrospective Study. PLOS ONE, 11(6):e0158045.doi:10.1371/journal.pone.0158045. (2016).

[17] Helm RE, Klausner JD, Klemperer JD, Flint LM, Huang E. Accepted but Unacceptable: Peripheral IV Catheter Failure. Infusion Nurses Society, 38(3): 189-203.(2015).

[18] Theresia SIM and Wardani Y. Contributing Factors in Increasing Health Care Associated Infection (Hai's) in Phlebitis Cases. Nurse Media Journal of Nursing, 5(1):48-55. (2015).

[19] Salma, U., Sarker, M., Zafrin, N., \& Ahamed, K. Frequency of Peripheral Intravenous Catheter Related Phlebitis and Related Risk Factors: A Prospective Study. Journal of Medicine, 20(1), 2933. https://doi.org/10.3329/jom.v20i1.38818. (2019).

[20] Atay S, Şen S, Çukurlu D. Phlebitis-related peripheral venous catheterization and the associated risk factors. Niger J Clin Pract;21:827-31. (2018).

[21] Elessandra SB, Camila NL, Radamés B, Verônica de Azevedo M, Jorge Vinícius Cestari F, Edivane Pedrolo. Revalence of Phlebitis Related to the use of Peripheral Intravenous Devices in Children. Cogitare Enferm, 23(1): e49361, http://dx.doi.org/10.5380/ce.v23i1.49361. (2018).

[22] Zohaib J, Muhammad U, Rabi Z, Nowera Z., Fatima R, Muhammad A.: Peripheral Intravenous Catheter related Thrombophlebitis- Incidence and Risk Factors A Cross Sectional Study. Journal of Rawalpindi Medical College; 23(S-1): 22-27. (2019).

[23] Jacinto AKL, Avelar AFM, Wilson AMMM, Pedreira MLG. Phlebitis associated with peripheral intravenous catheters in children: study of predisposing factors Escola Anna Nery Revista de Enfermagem 18(2):220-226. (2014).

[24] Gomes ACR, Silva CAG, Gamarra CJ, Faria JCO, Avelar AFM, Rodrigues EC. Avaliação da ocorrência de flebite, infiltração e extravasamento em neonatos submetidos à terapia intravenosa. Escola Anna Nery Revista de Enfermagem, 15(3):472-9. (2011).

[25] Doellman D, Hadaway L, Bowe-GeAddes LA, Franklin M, LeDonne J, Papke-O'Donnel L, et al. Infiltration and extravasation. J Infus Nurs. 2009; 32(4):203-211. (2009).

[26] Enes SMS, Opitz SP, Faro ARMC, Pedreira MLG. Phlebitis associated with peripheral intravenous catheters in adults admitted to hospital in the Western Brazilian Amazon. Rev Esc Enferm USP, 50(2):261-269. (2016). 
[27] Benaya A, Schwartz Y, Kory R, Ynnon AM, Ben-Chetrit E. Relative incidence of phlebitis associated with peripheral intravenous catheters in the lower versus upper extremities. Eur J Clin Microbiol Infect Dis, 34(5):913-6. (2015).

[28] Fang L, Fang SH, Chung YH. Factors affecting the unplanned peripheral reinsertion in pediatric patiernts from a teaching hospital in Taiwan. J Infus Nurs. 34(6):366-72. (2011).

[29] Pankaj Punjot, Jincy Mathew, Saly Suseel, Valsa A study to assess the effectiveness of infusion experts on the nursing interventions of peripheral intravascular devices among patients admitted to a tertiary care hospital of the city. Int J Nur Res. 4(3): -171-175. (2018). 